\title{
Exposure of Computer Games among IHL Students in Malaysia: Case Study of Computer Science Students in UiTM Terengganu
}

\author{
Hasiah Mohamed @,Omar \\ Faculty of Computer and Mathematical Sciences \\ Universiti Teknologi MARA (UiTM), \\ Dungun Campus, 2300 Dungun, Terengganu, Malaysia
}

Tel: 60-9-840-3835 E-mail: hasia980@tganu.uitm.edu.my

Nora Yanti Che Jan

Faculty of Computer and Mathematical Sciences

Universiti Teknologi MARA (UiTM)

Dungun Campus, 2300 Dungun, Terengganu, Malaysia

Tel: 60-9-840-3957Ｅ-mail: noray084@tganu.uitm.edu.my

\author{
Nik Marsyahariani Nik Daud \\ Faculty of Computer and Mathematical Sciences \\ Universiti Teknologi MARA (UiTM) \\ Dungun Campus, 2300 Dungun, Terengganu, Malaysia
}

Tel: 60-9-840-3770Ｅ-mail: nikma944@tganu.uitm.edu.my

\begin{abstract}
A survey on users' exposure of computer games among students of Institute of Higher Learning (IHL) has been done to gather useful information and relevant data regarding this study. This exploratory study focused on how exposure to computer games influenced students' academic performance in two computer science related subjects from the student's point of view. These two subjects were Fundamental of Computer Science (CSC119) and Introduction to Problem Solving (CSC125). The data was gathered from the questionnaire distributed among the whole population of Computer Science students from October-July 2007 intake (67 respondents) and then the data was analyzed using Statistical Package (SPSS version 12). From the analysis done, it is shown that respondents with early exposure score higher when compared to those with the late exposure.
\end{abstract}

Keywords: Exposure, Computer games, Computer related subject, Opinion

\section{Introduction}

Computer games have been a preference to most of computer users. Nowadays, it does not only focus on computer that we normally used in our office or house, but handheld devices such as handphone and Personal Digital Assistant (PDA) have also been a target platform for users to play computer games. Computer games come in various types to suit different user's requirement such as role playing game, educational game, sport game and entertainment game. Researches reveal that the focal group in computer games is adolescents (Griffiths \& Hunt, 1995; Subrahmanyam, Greenfield, Kraut, \& Gross, 2001).

There are many arguments regarding advantages and disadvantages of computer games towards users especially teenagers (Griffiths \& Hunt, 1995; Subrahmanyam et al., 2001). List of the advantages starts with computer games play an important role in education and it is adequate enough to assist many people, namely students, with their learning. Learning process in computer games can be achieved in formal and informal approach. Research suggests that computer games can actually be educative, beneficial and does help in human learning and development activities. Researchers have found that people who play computer games have better vision and computer games also assist students in improving hand-eye coordination and improve reflexes (Dorman, 1997; Emes, 1997; Tazawa \& Okada, 2001; Tazawa, 
Soukalo, Okada, \& Takada, 1997). Computer games also improve logical thinking and problem solving skills (Benton, 1995; Colwell, Grady, \& Rhaiti, 1995; Gentile \& Walsh, 2002; Pillary, Brownlee, \& Wilss, 1999). In the years that have followed, researchers found that educational software and games can indeed have several very positive effects on students' academic skills (Banks \& Miller, 2001; Greenfield, DeWinstanley, Kilpatrick, \& Kaye, 1996). As for the disadvantages, computer games have been discovered to cause eyestrain and chest pain (Tazawa et al., 1997) and sleep deprivation associated with black ring under the eyes and muscle stiffness in the shoulders (Tazawa \& Okada, 2001) to the players. Heavy computer gamers are also less sociable (Cowell \& Stanney, 2005; Roe \& Muijs, 1998). The increment in numbers of computer gamers is contributed by two main factors, which are the (1) accessibility of the computer games itself in terms of the software and platform and (2) variation of games categories offered in the market. Students are exposed to computer games not just as an entertainment but it has become a type of social tools. Derived from the trends and exposure are the curiosity that are very interesting to be explored in order to classify details on how students view it. Curiosities in our focus are interest, effects and exposure. However, in this paper only one curiosity will be highlighted, which is the exposure to computer games.

\subsection{Computer games}

The use of computer games nowadays has become popular among users despite their age and gender. This type of entertainment has become important to the users because of its functions - to release stress, learning process tools and there are various categories that can be chosen based on player's preferences, social life medium and popular leisure time activities (Poole, 2000; Vorderer \& Bryant, 2006). Computer games are defined as a set of activities involving one or more players. It has goals, constraints and consequences (Dempsey, Lucassen, Haynes, \& Casey, 1997). Elaborating further on that, Crawford (1984) said that a game is rule-guided and artificial in some aspects, and also involves some aspects of a contest or a trial of skill or ability, even if that contest is with oneself. According to him, there are four common factors that present in all games. These factors are representation, interaction, conflict and safety. So when the computer is used to present a game and to act as an opponent or as a referee, we have a computer game.

\subsection{Exposure to computer games}

Interactive media, such as video and computer games, have redefined today's leisure activities. These widely available games may be played on dedicated consoles systems, any computer and over the Internet, handheld devices and various technology toys. Several recent reports confirm that computer games have a significant present in the lives of children and adolescents (Buchman \& Funk, 1996; Gentile \& Walsh, 2002; Roberts, Foehr, Rideout, \& Brodie, 1999) \& Frunk, 1996; Gentile \& Walsh, 2002; Roberts, Foehr, Rideout \& Brodie, 1999; (Wright et al., 2001) and boys are avid consumers of computer games, playing nearly twice as frequently as girls (Roberts et al., 1999) also reported that children are spending an increasingly amount of time playing computer games. Computer games units are now present in $83 \%$ of homes with children. In 2004 alone, children spent 49 minutes per day playing computer games and on any given day, $52 \%$ of children aged $8-18$ years play games. Games use peaks during childhood, with an average of 65 minutes per day for $8-10$ years old and declines to 33 minutes per day for $15-18$ years old. A study conducted by (Gentile \& Walsh, 2002) found that the average American child aged 2-17 years plays games for 7 hours a week. This average marks wide differences between boys and girls and children in different ages. For example, in this study it is found that adolescent girls played games for an average of 5 hours a week whereas boys averaged 13 hours a week.

\section{Methodology}

In this exploratory study, 67 respondents of Part One Computer Science students in UiTM Terengganu were asked their opinions towards how the exposure to the computer games relate to their performance in two computer science related subjects (CSC119 and CSC125). The first phase in this exploratory study is planning and analysis where the problem mentioned earlier is to investigate study's significance. Analysis phase is being executed to find a suitable focus group and the best way to represent influences, effects and exposure of computer games in students' lifestyle. To ensure that the right methods are used, a thorough literature review was done during this phase.

The second and third phase are about designing and developing specific questionnaire to obtained data from students. In order to design the questionnaire, a preliminary survey has been done to find types of computer games that are played by the students. Developing questionnaire involved a few processes where the questionnaire is divided into five parts. Part A involves in collecting demographic data, while part B is to seek for categories of computer games that students prefer to play. Part $\mathrm{C}$ is dedicated for exposure and frequencies. Part $\mathrm{D}$ focuses on students' interest towards computer games and part E seeks for students' opinion on effects of computer games towards their lives. The questionnaires were distributed to students by the end of the semester. The distribution process is done with assistance from colleagues. Grades for each student in two computer related subjects, Fundamental of Computer Problem Solving (CSC125) and Fundamental of Computer Science (CSC119), are then collected to find any correlations. The data analysis phase involves analyzing data where the data obtained from the questionnaire and students' grade in the computer science related subjects by using statistical package which is SPSS version 12. This exploratory study is later documented as a finalized report. 


\subsection{Research tool}

Statistical methods used in this study to evaluate student response were based on descriptive technique. This technique was used to fit in with the requirement of the study which was categorized as an exploratory study. Sample for this study was taken from the whole population of Computer Science students from July-October 2007 intake. This was based on their level of exposure on academic life and to ensure that their knowledge toward computer usage was not influenced by their studies in UiTM. Questionnaire was used as the primary data collection tool in this exploratory study despite the other research methods such as interview and observation. The main reason for using questionnaire is because it can cover a wide range of sample and it is relatively cheap compared to other methods. Preliminary survey was conducted prior to the questionnaire. In our preliminary survey, a list of frequent play computer games was distributed to the students.

\subsection{Premilinary study}

A preliminary survey had been distributed to students at the beginning of semester July-October 2007. The survey was to seek for types of computer games that students frequently played. Students were asked to list down 10 of their most favorite's computer games. Based on the given answers, a list of computer games in Part B of the questionnaire is constructed. In this survey, all respondents are required to list 10 computer games that they often play. The list of the collected games was then divided into a few categories, which were based on literature review where different types of computer games categories had been discussed. All the computer games were divided into six main categories, which are action games, card and arcade games, role-playing and adventure games, sport games and strategy games.

\subsection{Questionnaire}

Questionnaire is divided into five main parts. Questions in Part A are prepared using open-ended question while Part B is constructed by listing out computer games based on category. Part B in the questionnaire was constructed using a list of computer games that are frequently played by this focus group. These computer games were selected based on the preliminary survey which has been explained in previous section. Not all games were selected as only 21 out of 49 listed games are listed in Part B. The total number of computer games in each category was varied as it was based on the students' survey result. From the survey, it seemed that most of the games picked out can be categorized as role-playing games. For each category, half of the listed games were taken to be included into the actual questionnaire. Part B was constructed using this technique to ensure that data collected can be easily analyzed. The list of computer games that are played by students can be controlled, and yet it is still based on the students' choice of computer games. Blank spaces are also provided for students to list any specific computer games if the game is not listed. Questions in part $\mathrm{C}$ were designed to be closed-ended questions.

Question in Part $\mathrm{C}$ focuses mainly in finding information regarding respondents' exposure and how frequent they play computer games. Question 2 in Part $\mathrm{C}$ asks the respondents to state their age when they are first expose to computer games. Age then being categorized based on their level and the categories are as follows: Kindergarten (4-6 years old), Lower Primary (7-9 years old), Upper Primary (10-12 years old), Lower Secondary (13-15 years old) and Upper Secondary (16-18 years old). Questions in Part D refers to students' interest towards computer games while Part E refers on effects of computer games based on students' opinion. Both questions in Part D and E are designed using Likert Scale.

Data that has been collected from the questionnaires were then analyzed using Statistical Packages for Social Sciences (SPSS) version 12. Statistic description used in this research was done based on percentage, frequencies and cross tabulation between students' achievements and their exposure in computer games. Data collected from all part of questionnaire are presented based on their percentage and frequencies while cross tabulation is applied to see the correlation between exposure's age and their results in computer related subjects.

\subsection{Data analysis}

Data that has been collected from the questionnaires were then analyzed using Statistical Packages for Social Sciences (SPSS) version 12. Statistic description used in this research was done based on percentage, frequencies and cross tabulation between students' achievements and their exposure in computer games. Data collected from all part of questionnaire are presented based on their percentage and frequencies while cross tabulation is applied to see the correlation between exposure's age and their results in computer related subjects.

\section{Result and discussion}

From the 67 questionnaire distributed, only 65 are returned. This gives the respond rate of $96.8 \%$. Most of the respondents prefer to play games that can be categorized into card and arcade games $(80 \%)$, followed by action games $(69.2 \%)$, role playing games $(63.1 \%)$, puzzle games $(50.8 \%)$, strategy games $(26.2 \%)$ and the least played games is in sport games category $(21.5 \%)$. This clearly shows that respondents have tendency towards computer games that challenge minds but in a more relaxing situation. A game that needs concentration and focus is more likely to be 
avoided.

\subsection{Exposure and frequency}

From the 65 returned questionnaire, it was found that $100 \%$ of the respondents are exposed to computer games. Table 1 shows in details percentage of age in which the respondents started to play computer games. From the table, majority of the respondents $(36.8 \%)$ were first introduced to computer games during their upper primary year which is 10 to 12 years old. Another $21.1 \%$ of the respondents came from a younger age level which is $7-9$ years old. Only $7 \%$ of the respondents started playing computer games at the age of 16 to 18 years old. This showed that most of the respondents have been exposed into computer games since their early age which is referring to 4-12 years old. When asked about their source of exposure, $67.2 \%$ of the respondents said they were introduced to computer games by friends. $23.4 \%$ mentioned there were exposed to computer games by the family members, 3.1\% said through school and $6.3 \%$ mentioned other sources. This clearly shown that their environment is quite supportive on encouraging the students to play computer games. Table 2 shows the details.

\subsection{Result analysis}

Comparison was made based on relation between respondents' result with their exposure age toward computer games. The cross tabulation can only be made using 57 respondents' data due to missing data on exposure age for 8 respondents (Part C question 2). Table 3 shows the cross tabulation between the exposure age and grade in CSC125 subject. Though early exposure in playing computer games cannot assure that the respondents will achieve a better grade in this subject, it seemed that respondents that are exposed to computer games at a later age tend to score lower. This can be observed based on the result where respondents that are exposed during their kindergarten, junior primary and senior primary (23 out of 57) get good grades while only 6 respondents from junior secondary and senior secondary manage to get good grades.

Table 4 shows the cross tabulation between the exposure age and grade in CSC119 subject. Respondents' marks seemed to be scattered all over the age range, but from an observation made on the table, 48 out of 57 respondents get good grades when they were exposed during their kindergarten, junior primary and senior primary phase. In contrast, there are only 9 respondents that manage to get good grades when exposed during their junior secondary and senior secondary phase.

\section{Conclusion}

Figure 1 shows the questionnaire that is used to collect data related to computer games exposure towards students in IHL. The questionnaire is divided into five parts. Part A is a section focusing on collecting data related with demographic. These data can be used to provide information such as gender and age and how these variables can be related to students' tendency on playing games. Part B or Category of Games is introduced to provide information regarding types of games that students prefer to play. Part $\mathrm{C}$ or Exposure and Frequency is prepared to find information on students' background and how can this be related to students' tendency in playing games. Part D is prepared to search for information on student interest toward computer games. This part is provided to validate on theory that students are influenced by computer games. Part E is the last section that is used to find out on students opinion on computer games.

This exploratory study is conducted to answer our curiosity about the relation between exposure to computer games and academic performance among adolescents. Scope of this study involved 67 Part One Computer Science students in UiTM Terengganu and two computer science related subjects which are CSC119 and CSC125. Student's opinions were gathered in order to answer the curiosity mentioned using research instrument which is questionnaire. At the final phase of the study, students' results for the two subjects were being analyzed to identify the relationship between students' opinion and their academic performance. It is proved that early exposure to computer games does help in students' academic performance.

\section{References}

Banks, J. S., \& Miller, N. R. (2001). Signaling games in political science Fundamentals of pure and applied economics. London: Routledge.

Benton, P. (1995). Conflicting cultures: Reflections on the reading and viewing of secondary-school pupils. Oxford Review of Education, 21(4), 457-470.

Buchman, D. D., \& Funk, J. B. (1996). Video and computer games in the '90s: children's time commitment and game preference. Children Today, 24(1), 12.

Colwell, J., Grady, C., \& Rhaiti, S. (1995). Computer games, self-esteem and gratification of needs in adolescents. Journal of Community \& Applied Social Psychology, 5(3),195-206. 
Cowell, A. J., \& Stanney, K. M. (2005). Manipulation of non-verbal interaction style and demographic embodiment to increase anthropomorphic computer character credibility. International Journal of Human-Computer Studies, 62(2), 281-306.

Crawford, C. (1984). The Art of Computer Game Design. Berkely, USA: Osborne/McGraw-Hill.

Dempsey, J. V., Lucassen, B. A., Haynes, L. L., \& Casey, M. S. (1997). An exploratory study of forty computer games (COE Technical Report No 97-2). Mobile, AL. University of South Alabama.

Dorman, S. M. (1997). Video and computer games: Effect on children and implications for health education. Journal of School Health, 67(4), 133-138.

Emes, C. E. (1997). Is Mr Pac Man eating our children? A review of the effect of video games on children. Canadian journal of psychiatry. Revue canadienne de psychiatrie, 42(4), 409.

Gentile, D. A., \& Walsh, D. A. (2002). A normative study of family media habits. Journal of Applied Developmental Psychology, 23(2), 157-178.

Greenfield, P. M., DeWinstanley, P., Kilpatrick, H., \& Kaye, D. (1996). Action video games and informal education: Effects on strategies for dividing visual attention. Interacting with video, 11, 187-205.

Griffiths, M. D., \& Hunt, N. (1995). Computer game playing in adolescence: Prevalence and demographic indicators. Journal of Community \& Applied Social Psychology, 5(3),189-193.

Pillary, H., Brownlee, J., \& Wilss, L. (1999). Cognition and recreational computer games: Implications for educational technology. Journal of Research on Computing in Education, 32(1), 203-216.

Poole, S. (2000) Trigger Happy: The Inner Life of Videogames.London: Fourth Estate.

Roberts, D. F., Foehr, U. G., Rideout, V. J., \& Brodie, M. (1999). Kids \& media@ the new millennium. Menlo Park, CA: Kaiser Family Foundation.

Roe, K., \& Muijs, D. (1998). Children and computer games: A profile of the heavy user. European Journal of Communication, 13(2), 181.

Subrahmanyam, K., Greenfield, P., Kraut, R., \& Gross, E. (2001). The impact of computer use on children's and adolescents' development. Journal of Applied Developmental Psychology, 22(1), 7-30.

Tazawa, Y., \& Okada, K. (2001). Physical signs associated with excessive television-game playing and sleep deprivation. Pediatrics International, 43(6), 647.

Tazawa, Y., Soukalo, A. V., Okada, K., \& Takada, G. (1997). Excessive playing of home computer games by children presenting unexplained symptoms. Journal of Pediatrics, 130(6), 1010.

Vorderer, P., \& Bryant, J. (2006). Playing Video Games: Motives, Responses, and Consequences.NJ: Lawrence Erlbaum.

Wright, J. C., Huston, A. C., Vandewater, E. A., Bickham, D. S., Scantlin, R. M., \& Kotler, J. A., et al. (2001). American children's use of electronic media in 1997: A national survey. Journal of Applied Developmental Psychology, 22(1), 31-47.

Table 1. Age starting to play computer games

\begin{tabular}{|c|c|c|}
\hline Level & Frequency & Percentage \\
\hline Kindergarten (4-6 years old) & 8 & 14.0 \\
\hline Lower Primary (7-9 years old) & 12 & 21.1 \\
\hline Upper Primary (10-12 years old) & 21 & 36.8 \\
\hline Lower Secondary (13-15 years old) & 12 & 21.1 \\
\hline Upper Secondary (16-18 years old) & 4 & 7.0 \\
\hline
\end{tabular}

Table 2. Source of computer games

\begin{tabular}{|c|c|}
\hline Source & Percentage \\
\hline Friends & 67.2 \\
\hline Family & 23.4 \\
\hline School & 3.1 \\
\hline Others & 6.3 \\
\hline
\end{tabular}


Table 3. Relation between exposure age and CS125 grade

\begin{tabular}{|c|c|c|c|c|c|c|}
\hline & & \multicolumn{5}{|c|}{ Exposure age } \\
\hline & & Kindergarten & $\begin{array}{c}\text { Junior } \\
\text { Primary }\end{array}$ & $\begin{array}{l}\text { Senior } \\
\text { Primary }\end{array}$ & $\begin{array}{c}\text { Junior } \\
\text { Secondary }\end{array}$ & $\begin{array}{c}\text { Senior } \\
\text { Secondary }\end{array}$ \\
\hline \multirow{12}{*}{ 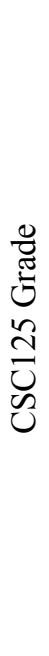 } & $\mathrm{A}+$ & 0 & 1 & 0 & 0 & 0 \\
\hline & A & 2 & 0 & 0 & 1 & 0 \\
\hline & A- & 2 & 1 & 1 & 0 & 0 \\
\hline & $\mathrm{B}+$ & 1 & 3 & 4 & 2 & 0 \\
\hline & B & 0 & 1 & 3 & 0 & 0 \\
\hline & B- & 1 & 1 & 2 & 3 & 0 \\
\hline & $\mathrm{C}+$ & 0 & 1 & 5 & 1 & 0 \\
\hline & $\mathrm{C}$ & 0 & 2 & 2 & 0 & 3 \\
\hline & $\mathrm{C}-$ & 1 & 0 & 1 & 3 & 0 \\
\hline & $\mathrm{D}+$ & 0 & 1 & 0 & 1 & 0 \\
\hline & $\mathrm{D}$ & 1 & 1 & 1 & 1 & 0 \\
\hline & $\mathrm{E}$ & 0 & 0 & 2 & 0 & 1 \\
\hline
\end{tabular}

Table 4. Relation between exposure age and CS119 grade

\begin{tabular}{|c|c|c|c|c|c|c|}
\hline & & \multicolumn{5}{|c|}{ Exposure age } \\
\hline & & Kindergarten & $\begin{array}{c}\text { Junior } \\
\text { Primary }\end{array}$ & $\begin{array}{c}\text { Senior } \\
\text { Primary }\end{array}$ & $\begin{array}{c}\text { Junior } \\
\text { Secondary }\end{array}$ & $\begin{array}{c}\text { Senior } \\
\text { Secondary }\end{array}$ \\
\hline \multirow{10}{*}{ 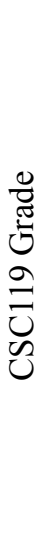 } & $\mathrm{A}+$ & 0 & 1 & 0 & 0 & 0 \\
\hline & A & 0 & 4 & 3 & 2 & 0 \\
\hline & A- & 5 & 2 & 3 & 1 & 1 \\
\hline & $\mathrm{B}+$ & 1 & 1 & 3 & 2 & 1 \\
\hline & $\mathrm{B}$ & 0 & 2 & 5 & 3 & 1 \\
\hline & B- & 0 & 1 & 2 & 3 & 1 \\
\hline & $\mathrm{C}+$ & 1 & 0 & 4 & 0 & 0 \\
\hline & $\mathrm{C}$ & 1 & 0 & 1 & 0 & 0 \\
\hline & $\mathrm{C}-$ & 0 & 1 & 0 & 0 & 0 \\
\hline & $\mathrm{D}$ & 0 & 0 & 0 & 1 & 0 \\
\hline
\end{tabular}

Figure 1 Questionnaire: Students Opinion Towards Influence Of Computer Games: Case Study Of Part One Computer Science Students In UiTM Terengganu

\section{Part A (Demographic Data)}

Please fill in the information required below.

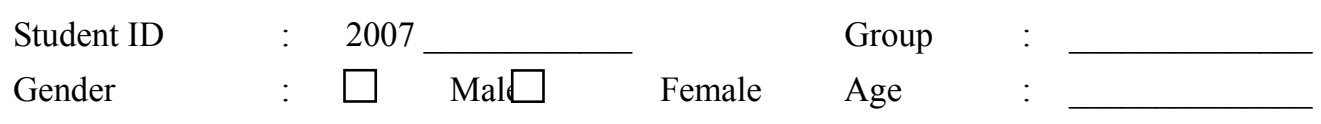

Hometown 
Part B (Category of Games)

Select $(\sqrt{ }) 5$ games that you often play from the list below. If the game is not listed, write it in the space provided.

\begin{tabular}{|l|l|l|l|l|l|}
\hline & 1. Need for Speed & & 8. Winning Eleven & & 15. Half Life \\
\hline & 2. Diner Dash & & 9. Hangaroo & & 16. Ragnarok \\
\hline & 3. King of Fighter & & 10. Minesweeper & & 17. Grand Theft Auto \\
\hline & 4. Lord of The Ring & & 11. Bejewelled & & 18. Daytona \\
\hline 5. Pinball & & 12. Zuma & & 19. FIFA World Cup \\
\hline & 6. Mario & & 13. Final Fantasy & & 20. The Sims \\
\hline & 7. Solitaire & & 14. Counter Strike & & 21. Command and Conquer \\
\hline & & & & \\
\hline
\end{tabular}

\section{Part C (Exposure and Frequency)}

Please tick $(\sqrt{ })$ in the appropriate box.

1. Do you play computer games? If not, go to Part E
$\square$ Yes $\square$ No

2. When did you start playing computer games? (State your age) years old

3. Do you use computer at home?

$\square$ Yes $\square$ No

4. Where do you usually play computer games?

$\square$ Home $\square$ Cyber Café $\square$ Friend's home $\square$ Others (Please specify)

5. What type of computer games do you usually play?
$\square$ PC games
$\square$ Online games
Games Console (PS2/PS3/Xbox)

6. Where do you usually get the software for the computer games?
$\square$ Buy
Friends
Download from the Internet
Others (Please specify)

7. Who introduced you to computer games?
$\square$ Friends
Family members
$\square$ School (computer class)
$\square$ Others (Please specify)

8. How often do you play computer games?
$\square$ Everyday
$\square 1-2$ times/week
1- 2 times/month
less than once a month

9. How many hours do you normally spend each time you play computer games?

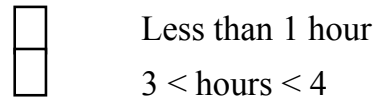
$\square \begin{aligned} & 1<\text { hours }<2 \\ & 4<\text { hours }<5\end{aligned}$
$\square \begin{aligned} & 2<\text { hours }<3 \\ & \text { more than } 6 \text { hours }\end{aligned}$ 


\section{Part D (Students Interest towards Computer Games)}

Circle your answer.

\begin{tabular}{|lccccc|}
\hline Questions & $\begin{array}{c}\text { Strongly } \\
\text { Disagree }\end{array}$ & Disagree & $\begin{array}{c}\text { Neutra } \\
\text { I }\end{array}$ & $\begin{array}{c}\text { Agree } \\
\begin{array}{l}\text { Strongly } \\
\text { Agree }\end{array}\end{array}$ & $\begin{array}{c}\text { 1. I like to play computer games. } \\
\begin{array}{l}\text { 2. I like to spend most of my time playing computer } \\
\text { games. }\end{array}\end{array}$ \\
$\begin{array}{l}\text { 3. I do not realize how time goes by while playing } \\
\quad \text { computer games. }\end{array}$ & 1 & 2 & 3 & 4 & 5 \\
$\begin{array}{l}\text { 4. If possible, I want to play computer games } \\
\text { everyday. }\end{array}$ & 1 & 2 & 3 & 4 & 5 \\
\hline \begin{tabular}{l} 
5. I like to try out new computer games. \\
\hline
\end{tabular} & 1 & 2 & 3 & 4 & 5 \\
\hline
\end{tabular}

\section{Part E (Students Opinion on Computer Games)}

Circle your answer.

\begin{tabular}{|c|c|c|c|c|c|}
\hline Questions & $\begin{array}{l}\text { Strongly } \\
\text { Disagree }\end{array}$ & Disagree & $\begin{array}{c}\text { Neutra } \\
1\end{array}$ & Agree & $\begin{array}{c}\text { Strongly } \\
\text { Agree }\end{array}$ \\
\hline $\begin{array}{l}\text { 1. Playing computer games will help me improve } \\
\text { my academic performance. }\end{array}$ & 1 & 2 & 3 & 4 & 5 \\
\hline $\begin{array}{l}\text { 2. Playing computer games will increase my } \\
\text { critical and logical thinking. }\end{array}$ & 1 & 2 & 3 & 4 & 5 \\
\hline $\begin{array}{l}\text { 3. Playing computer games will increase my } \\
\text { knowledge on computers. }\end{array}$ & 1 & 2 & 3 & 4 & 5 \\
\hline $\begin{array}{l}\text { 4. Playing computer games will help me release } \\
\text { stress. }\end{array}$ & 1 & 2 & 3 & 4 & 5 \\
\hline $\begin{array}{l}\text { 5. Playing computer games is more beneficial } \\
\text { than other leisure activities. }\end{array}$ & 1 & 2 & 3 & 4 & 5 \\
\hline $\begin{array}{l}\text { 6. Playing computer games helps me get good results } \\
\text { in programming subject (CSC125) }\end{array}$ & 1 & 2 & 3 & 4 & 5 \\
\hline $\begin{array}{l}\text { 7. Playing computer games will help me get } \\
\text { good results in computer subject (CSC119). }\end{array}$ & 1 & 2 & 3 & 4 & 5 \\
\hline $\begin{array}{l}\text { 8. My academic performance will decrease } \\
\text { because I play computer games. }\end{array}$ & 1 & 2 & 3 & 4 & 5 \\
\hline $\begin{array}{l}\text { 9. I do not have many friends because of } \\
\text { computer games. }\end{array}$ & 1 & 2 & 3 & 4 & 5 \\
\hline 10. Playing computer games makes me passive & 1 & 2 & 3 & 4 & 5 \\
\hline
\end{tabular}

